\title{
Computed tomography angiography imaging of the ductus arteriosus aneurysm in a neonate
}

\author{
Yenidoğanda duktus arteriyozus anevrizmasının bilgisayarlı tomografi anjiografi ile \\ gösterilmesi
}

\author{
Kadir Ağladıoğlu*, Dolunay Gürses**, Hacer Ergin**, Mustafa Doğan**, Bilgin Emrecan*** \\ *Pamukkale Üniversitesi Tıp Fakültesi, Radyoloji AD, Denizli \\ ${ }^{* *}$ Pamukkale Üniversitesi Tıp Fakültesi, Pediatri AD, Denizli \\ ***Pamukkale Üniversitesi Tıp Fakültesi, Kalp Damar Cerrahisi, Denizli
}

\begin{abstract}
Ductus arteriosus aneurysm (DAA) is a rare and fatal abnormality. Pulmonary hypertension, refractory heart failure and left ventricular loading developed in a 6-day-old female neonate diagnosed with transient tachypnea of the newborn (TTN). In the echocardiography, aortic arc abnormality and ductus arteriosus aneurysm (DAA) was suspected. Computed tomography angiography (CTA) was performed to prove the diagnosis. In the CTA, an aneurysmatic dilatation was observed in the ductus arteriosus and an aneurysectomy was performed surgically. To the best of our knowledge, the present study is the second case of pulmonary hypertension due to DAA in the English literature. In this case report, we aim to emphasize the contribution of CTA to the diagnosis of DAA.
\end{abstract}

Pam Med J 2015;8(1):63-65

Key words: Ductus arteriosus aneurysm, computed tomography angiography, pulmonary hypertension.

\section{Özet}

Duktus arteriyozus anevrizması, nadir görülen ve fatal bir anomalidir. Yenidoğanın transient takipnesi tanısı bulunan 6 günlük kız bebekte pulmoner hipertansiyon, refrakter kalp yetmezliği ve sol ventrikül yüklenme bulguları gelişti. Ekokardiografisinde aortik ark anomalileri ve duktus arteriyozus anevrizmasından (DAA) şüphelenildi. Tanıyı kesinleştirmek için bilgisayarlı tomografi anjiografi (BTA) yapıldı. BTA' da duktus arteriyozusta anevrizmatik dilatasyon saptandı ve cerrahi işlemle anevrizektomi yapıldı. En iyi bilgilerimize göre İngiliz literatüründe DAA'ya bağlı pulmoner hipertansiyon gelişen iki olgu vardır. Bu olgu sunumunda, DAA'nın tanısında BTA'nın katkısını vurgulamaya çalıştık.

Pam Tıp Derg 2015;8(1):63-65

Anahtar sözcükler: Duktus arteriyozus anevrizma, bilgisayarlı tomografi anjiografi, pulmoner hipertansiyon.

\section{Introduction}

The exact incidence of congenital ductus arteriosus aneurysm (DAA) is not known; however, Jan et al. reported an incidence of $8.8 \%$ in their prospective study [1]. DAA that becomes symptomatic in the first 24 hours of life is rare [2,3]. Symptoms are secondary to thromboembolism, infection, airway erosion or compression of thoracic structures in most of the cases [1-3]. This study presents a neonatal case with a large ductal aneurysm presenting immediately after birth with a poor general condition, transient tachypnea of the newborn
(TTN), severe heart failure, signs of left ventricular loading and pulmonary hypertension.

\section{Case Report}

Computed tomography angiography (CTA) was performed on a 6-day-old intubated female neonate admitted with a poor general condition, TTN, heart failure and pulmonary hypertension due to a suspicious aortic arc abnormality and potential ductal aneurysm in the echocardiography (Figure 1). Pulmonary hypertension was diagnosed by echocardiography. Three

Kadir Ağladıoğlu

Yazışma Adresi: Pamukkale Üniversitesi Tıp Fakültesi Radyoloji AD, Denizli

e-mail: kadiragladi@yahoo.com

Gönderilme tarihi: 22.06.2014

Kabul tarihi: 22.10 .2014 
dimensional CTA revealed an $11.8 \times 10.3 \mathrm{~mm}$ aneurysmatic dilatation of the ductus arteriosus (Figure 2 and figure 3 ). The diagnosis of a patent DAA was confirmed in surgery and an aneurysmectomy was performed.

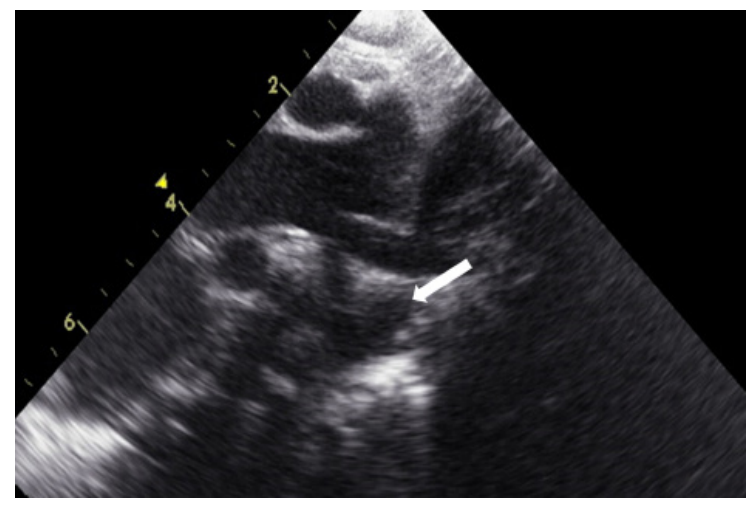

Fig 1. By echocardiography, a segmentary stenosis is observed at the arcus aorta immediately after the branching of left subclavian artery. An aneurysmatic dilatation is observed at the distal portion of this segment (arrow).

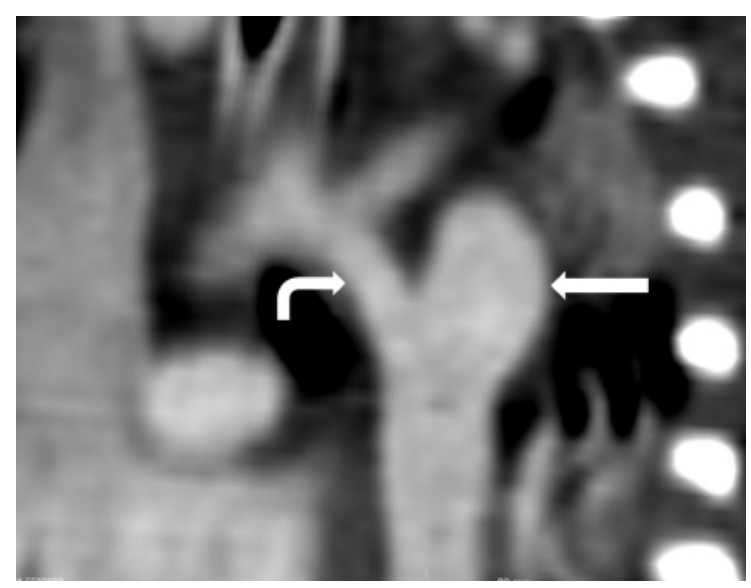

Figure 2. A segmentary stenosis (serpentine arrow) in the arcus aorta right after the left subclavian artery branch and ductus arteriosus aneurysm (straight arrow) at the distal portion of this segmentary stenosis is observed in MIP images obtained from CTA images (MIP=Maximum intensity projection, $C T A=$ computed tomography angiography).

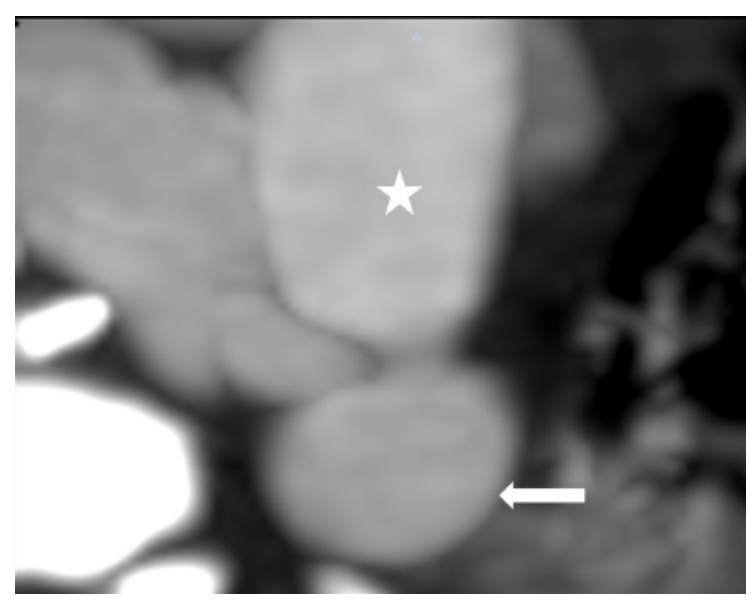

Fig 3. CTA which shows the DAA (arrow) merges with the superior portion of main pulmonary branch (asterisk) with a narrow orifice (DAA= ductus arteriosus aneurysm, CTA=computed tomography angiography).

\section{Discussion}

Congenital DAA is often asymptomatic and remains unnoticed in most neonates [4]. However, the patient in this paper was diagnosed with DAA in the newborn period due to pulmonary hypertension with heart failure. Jan et al. [2] reported 48 asymptomatic cases. In a review of 61 cases reported by Lund et al, the rate of lethal DAA complications was $30 \%$. And these complications have been reported as thromboembolism, rupture, dissection, and infection [3]. Koneti et al. [4] reported 4 neonates with DAA presenting with symptoms of respiratory distress, stridor, intercostal retraction, and weak crying resulting from the compression of DAA on the surrounding tissues. Additionally, compression on surrounding tissues such as the phrenic nerve, left main bronchi, and recurrent laryngeal nerve were reported [5-7]. On the other hand, Dyamenahalli et al. [1] reported only 4 symptomatic cases of 15 postnatal DDA cases. These symptomatic cases presented with symptoms of aortic rupture, stridor, and cyanosis, which were secondary to right ventricular dysfunction. Only one of these cases was determined with pulmonary hypertension just like this case. The patient in this paper had left heart failure with pulmonary hipertension. To the best of the authors knowledge, this is the second case with symptomatic pulmonary hipertension with DAA. Although DAA is known to regress spontaneously following the closure of the ductus arteriosus in infants with asymptomatic ductal aneurysm, surgical resection is recommended in symptomatic ductal aneurysms [8]. 
Even though traditional DAA is diagnosed by two-dimensional echocardiogram, some patients require further studies such as CTA or MR angiography (MRA). These examinations should be performed following echocardiographic investigations to determine the location and size of the aneurysm as well as its relationship with the surrounding tissues (1). Three-dimensional CT angiography is rarely used as a diagnostic tool in DAA diagnosed in neonatal cases (9).

In conclusion, CTA is one of the noninvasive methods that can be used to determine the morphology of DAA. We believe that potential intra-operative complications might be minimized with the performance of CTA or MRA.

Conflict of interest: The authors declared no conflict of interest.

\section{References}

1. Dyamenahalli U, Smallhorn JF, Geva T, Fouron JC, Cairns P, Jutras L, Hughes V, Rabinovitch M, Mason CA, Hornberger LK: Isolated ductus arteriosus aneurysm in the fetus and infant: a multi-institutional experience. J Am Coll Cardiol 2000, 36(1):262-269.

2. Jan SL, Hwang B, Fu YC, Chai JW, Chi CS: Isolated neonatal ductus arteriosus aneurysm. J Am Coll Cardiol 2002, 39(2):342-347.

3. Lund JT, Hansen D, Brocks V, Jensen MB, Jacobsen JR: Aneurysm of the ductus arteriosus in the neonate: three case reports with a review of the literature. Pediatr Cardiol 1992, 13(4):222-226.

4. Koneti NR, Kanchi V, Kandraju H, Jaishankar S: Symptomatic aneurysm of ductus arteriosus in neonates. Ann Pediatr Cardiol 2011, 4(2):159-163.

5. Das BB, Solowiejczyk DE, Kamath V, Sharma J: Congenital ductus arteriosus aneurysm presenting with stridor in a newborn. J Perinatol 2002, 22(2):179-180.

6. Heikkinen ES, Simila S: Aneurysm of ductus arteriosus in infancy: report of two surgically treated cases. J Pediatr Surg 1972, 7(4):392-397.

7. Hornung TS, Nicholson IA, Nunn GR, Hawker RE: Neonatal ductus arteriosus aneurysm causing nerve palsies and airway compression: surgical treatment by decompression without excision. Pediatr Cardiol 1999, 20(2):158-160.

8. Oh SJ, Jeung IC: A case of isolated congenital ductus arteriosus aneurysm detected by fetal echocardiography at 38 weeks of gestation. J Clin Ultrasound 2011, 39(9):530-533.

9. Colyer J, Heath D, Cross R: Diagnosis of ductal aneurysm using three-dimensional CT reconstruction. Pediatr Cardiol 2010, 31(2):301-302. 